\title{
Effect of flint corn processing method and roughage level on finishing performance of Nellore-based cattle ${ }^{1}$
}

\author{
M. Caetano, ${ }^{* 2}$ R. S. Goulart, $*$ S. L. Silva, $\dagger$ J. S. Drouillard, $\uparrow$ P. R. Leme, $\uparrow$ and D. P. D. Lanna*3 \\ *University of São Paulo, Luiz de Queiroz College of Agriculture, \\ Department of Animal Science, Piracicaba, São Paulo, Brazil, 13418900; †University of São Paulo, \\ College of Animal Science and Food Engineering, Department of Animal Science, Pirassununga, São Paulo, \\ Brazil, 13635900; and †Kansas State University, Department of Animal Sciences and Industry, Manhattan 66506
}

\begin{abstract}
This study was conducted to evaluate the effects of flint corn processing method (CPM) and level of NDF from roughage (rNDF) on performance, carcass characteristics, and starch utilization by finishing Nellore-based cattle fed high-concentrate, flint corn-based diets. In this study, 112 Nellore type bulls (initial BW $384.07 \pm 29.53 \mathrm{~kg}$ and $24-36 \mathrm{mo}$ of age) were individually fed using Calan gates or individual pens. The animals were used in a randomized complete block design in a $2 \times 4$ factorial arrangement with $2 \mathrm{CPM}$, high-moisture flint corn (HMC) or finely ground dry flint corn (FGC), with 1 of 4 levels of rNDF, 3, 8, 13, and 18\% (DM basis), using sugarcane silage (SS) as roughage. Bulls were adapted to the finishing diet over a $21-\mathrm{d}$ period and fed for a total of $81 \mathrm{~d}$. Fecal starch (FS) concentration was determined on $\mathrm{d} 46$ and 74 of the feeding period. There was a quadratic effect of rNDF on final BW $(P<0.01)$ and $\operatorname{ADG}(P=0.01)$. Optimal concentrations of $\mathrm{rNDF}$ were estimated using the first derivative of second order polynomials, indicating that final $\mathrm{BW}$ and $\mathrm{ADG}$ were maximized with 13.3 and $13.0 \%$ rNDF, respectively. An interaction was observed between CPM and
\end{abstract}

rNDF $(P=0.05)$ for DMI, with peak DMI occurring at 11.3 and $13.7 \%$ rNDF with FGC and HMC, respectively. Cattle fed HMC had $13.9 \%$ greater G:F $(P<$ $0.01)$ compared with those fed FGC ( 0.172 vs. 0.151 , respectively). There were quadratic effects of rNDF on HCW $(P=0.04)$ and ME intake $(P<0.01)$; heaviest carcass weights were estimated, in both cases, to be achieved with $12.8 \%$ rNDF. A quadratic effect of rNDF for renal, pelvic, and inguinal fat weight $(P=$ $0.04)$ was observed, with a peak estimated to occur at $12.6 \%$ rNDF. An interaction between CPM and rNDF also was observed for FS $(P<0.05)$. Bulls fed FGC with 3\% rNDF had greater FS content, and FS linearly decreased as concentration of rNDF increased. For bulls fed HMC, FS was $3.0 \%$ of DM and was unaffected by rNDF in the diet. Lower FS from bulls fed HMC suggests that availability of starch from flint corn was greater than that of FGC. For Nellore-based cattle fed a flint corn-based diet containing SS and $8 \%$ whole lint cottonseed, performance was optimized with $12.8 \%$ rNDF. In the absence of cottonseed addition to diets, optimal performance would be expected with about $14.5 \%$ rNDF.

Key words: fecal starch, finely ground corn, flint corn, high-moisture corn, Nellore, roughage

(C) 2015 American Society of Animal Science. All rights reserved. J. Anim. Sci. 2015.93:4023-4033 doi:10.2527/jas2015-9051

\footnotetext{
${ }^{1}$ This project was financially supported by FAPESP (Fundação de Amparo à Pesquisa do Estado de São Paulo; 2008/58903-8), CNPq (Conselho Nacional Desenvolvimento Científico e Tecnológico; 142558/2009-5 and 200860/2011-9), and CAPES (Coordenação de Aperfeiçoamento de Pessoal de Nível Superior) for the first author's scholarship. The authors thank Mario De Beni Arrigoni and Cyntia Ludovico Martins at UNESP (Universidade Estadual Paulista), Botucatu Campus; the students Anderson Roberto Cabral, Andréa Cristina Ianni, Daiane Cristina Marques da Silva, Geovani Bertochi Feltrin, João Gustavo Rebelato Forti, Luís Marcelo Nave
}

Sarti, Marina de Nadai Bonin, Pâmela Marcos Rizzo, Rafaela Torrezan Privatti, Robson Sfaciotti Barducci, Thaila Fernanda de Moura, and Vitor Augusto Bertollucci da Silva; and the companies Cargill, Casale, Dow AgroScience, Katec-Lallemand, Louis Dreyfus Commodities, Menta, Novanis, and Phibro.

${ }^{2}$ The University of Adelaide, School of Animal and Veterinary Sciences, Roseworthy, South Australia, Australia, 5371

${ }^{3}$ Corresponding author: dplanna@usp.br

Received February 27, 2015.

Accepted June 9, 2015. 


\section{INTRODUCTION}

When compared on a DE basis, forages generally are more costly than grains, but roughages are essential for avoidance of metabolic disorders and to optimize daily gains of cattle fed grain-based diets (Stock et al., 1990). The range in roughage levels is much larger in Brazilian feedlots than in North America (Millen et al., 2009). Cattle performance and DMI responses to different roughage sources vary in proportion to their NDF concentration (Shain et al., 1999; Galyean and Defoor, 2003). Therefore, the content of NDF from roughage (rNDF) should be considered when formulating feedlot diets (Galyean and Defoor, 2003). Nellore cattle are the predominant beef breed type in Brazil. Feedlot performance of Nellore-based cattle often is poorer than that of Bos taurus crossbred cattle (Marcondes et al., 2011). When fed high-grain diets, relatively high fecal loss of starch has been observed in Bos indicus cattle (Olbrich, 1996). Grain processing frequently has been the subject of feedlot cattle experiments, but the corn used in these experiments normally has consisted of soft endosperm types rather than the flint corn that makes up over $78 \%$ of grain produced in Brazil (Cruz et al., 2012). Flint corn is characterized by slower ruminal starch degradation (Correa et al., 2002) and, consequently, poorer cattle growth and efficiency. High-moisture ensiling improves starch digestion by ruminants when compared with dry grain processing methods such as grinding or cracking (Owens and Zinn, 2005). High-moisture flint corn (HMC) should be a viable method to improve utilization of flint corn by Nellore cattle. The objectives of this study were to evaluate effects of various levels of rNDF on feedlot performance, carcass characteristics, and starch utilization by Nellore-based cattle fed flint corn diets containing either HMC or finely ground dry flint corn (FGC).

\section{MATERIALS AND METHODS}

Animal care and handling techniques were approved by Animal Care and Committee of the University of São Paulo, Luiz de Queiroz College of Agriculture. The trial was conducted at University of São Paulo, College of Animal Science and Food Engineering (USP/FZEA) in Pirassununga, São Paulo, Brazil.

\section{Sugarcane Silage and Corn Processing Method}

Sugarcane silage (SS; SP91-1049) to be used as a roughage source was harvested and chopped, 10 mo after planting, using a Colhiflex 2008 MFC-1 chopper (Menta Mit Máquina Agrícolas Ltda, Cajuru, SP, Brazil). During the process of packing the SS into the silo, it was sprayed with a solution containing Lactobacillus buchneri (strain NCIMB 40788-LALSIL Cana; Lallemand Animal Nutrition, Aparecida de Goiânia, GO, Brazil) at a rate of $5 \times 10^{10} \mathrm{cfu} / \mathrm{t}$, and the stack was covered with a double layer silage pit cover $(150 \mu \mathrm{m}$ thick).

The corn hybrid, DOW 2B707 from Dow AgroScience (Santo Amaro, SP, Brazil), was planted in sufficient quantity for the entire experiment at USP/ FZEA. For HMC, half of the field was harvested when the corn kernels contained $40 \%$ moisture, at $109 \mathrm{~d}$ after planting. The HMC was ground using a Silotress Poelter OP20 model series 00200 grinder (Heritage UNESP-Botucatu; Boelter, Gravataí, RS, Brazil), packed into a silage bag (double layer, $150 \mu \mathrm{m}$ thick), and stored for 6 mo before being fed. Moisture content of the ensiled corn was $39.9 \%$.

For FGC, the remaining half of the field was harvested $157 \mathrm{~d}$ after planting at a kernel moisture content of $19 \%$. The grain was dried to $13 \%$ moisture and stored in metal grain bins.

\section{Animals and Feedlot}

One hundred twelve Nellore type bulls (384.1 \pm $29.53 \mathrm{~kg}$ initial BW; 24 to 36 mo of age) were used in a randomized complete block (initial $\mathrm{BW}$ ) design, with a $2 \times 4$ factorial arrangement of treatments to test interactions between corn processing method (CPM; HMC and FGC) and level of roughage (3, 8, 13, and $18 \%$ of NDF from SS), using 14 replications per treatment.

Before shipment to the feedlot, bulls received ivermectin (Jofadel Indústria Farmacêutica, Varginha, MG, Brazil); vitamins A, D, and E (Hertape Calier, Juatuba, MG, Brazil); clostridial vaccine (OuroFino, Cravinhos, SP, Brazil); and, $30 \mathrm{~d}$ after arrival, albendazole(OuroFino). During the experiment, animals were vaccinated against foot and mouth disease (Vallée, São Paulo, SP, Brazil) in accordance with Brazilian national immunization dates. One day before the study began, bulls were identified with an ear tag and BW, wither height, and hip height were measured. Bulls were blocked by initial BW and randomly assigned, within block, to treatments and individual gates and pens. There were 2 blocks with 48 animals each and 1 block with 16 animals. One bull did not complete the study for reasons unrelated to treatment (sciatic nerve trauma).

On arrival to the feedlot, before step-up diets, bulls were fed a diet containing (DM basis) $42.5 \%$ sugarcane bagasse, $21 \% \mathrm{SS}, 20 \%$ FGC, $15 \%$ soybean meal, $0.80 \%$ limestone, and $0.70 \%$ urea. Bulls were gradually adapted to high-grain diets over a $21-d$ period using 2 step-up diets. The 2 different CPM were applied from the first day of adaptation until the last day of this study. The first $6 \mathrm{~d}$ of adaptation, bulls were fed a diet containing (DM 
Table 1. Composition of experimental $\operatorname{diets}^{1}$ (DM basis)

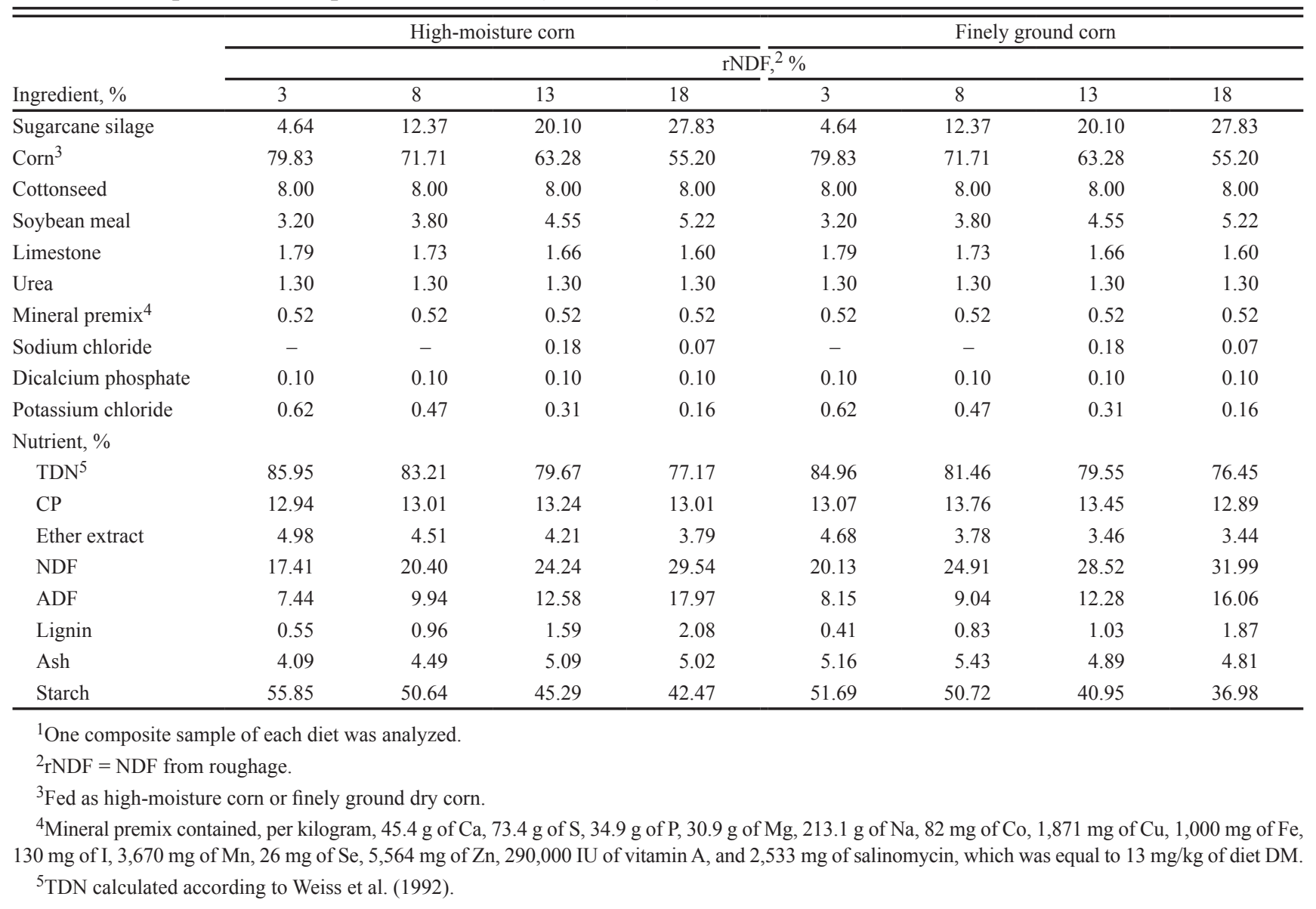

basis) $40 \% \mathrm{SS}, 22.17 \%$ processed corn, $15.55 \%$ soybean hulls, 12\% whole lint cottonseed (WLC), 7.50\% soybean meal, $1.25 \%$ limestone, $0.70 \%$ urea, $0.52 \%$ mineral premix, $0.21 \%$ sodium chloride, and $0.10 \%$ dicalcium phosphate. The second diet, fed from 7 until 12 d, contained (DM basis) $30.11 \% \mathrm{SS}, 40.57 \%$ processed corn, $10 \%$ soybean hulls, $10.77 \%$ WLC, $5.30 \%$ soybean meal, $1.43 \%$ limestone, $1.00 \%$ urea, $0.52 \%$ mineral premix, $0.20 \%$ sodium chloride, and $0.10 \%$ dicalcium phosphate. The mineral premix contained, per kilogram, $45.4 \mathrm{~g} \mathrm{Ca}, 73.4 \mathrm{~g} \mathrm{~S}, 34.9 \mathrm{~g} \mathrm{P}, 30.9 \mathrm{~g} \mathrm{Mg}, 213.1 \mathrm{~g} \mathrm{Na}, 82$ mg Co, 1,871 mg Cu, 1,000 mg Fe, $130 \mathrm{mg} \mathrm{I,} \mathrm{3,670} \mathrm{mg}$ Mn, 26 mg Se, 5,564 mg Zn, 290,000 IU vitamin A, and $2,533 \mathrm{mg}$ salinomycin (equivalent to $13 \mathrm{mg} / \mathrm{kg}$ of diet $\mathrm{DM})$. For the last $9 \mathrm{~d}$ of adaptation, a gradual change to higher energy density diets was made every $3 \mathrm{~d}$. This was performed only for bulls assigned to treatments with lower inclusions of rNDF, and by d 22, all bulls were consuming their final finishing diets (Table 1).

Bulls were fed fresh feed twice daily at 0700 and $1630 \mathrm{~h}$. Orts were removed twice weekly or as necessary due to rain. The quantity of feed provided daily for each bull was estimated using bunk scores (Pritchard, 1998) to provide near ad libitum access to feed.
Samples of all ingredients and diets were collected weekly throughout the study to determine chemical composition, mainly for SS, HMC, and FGC (Table 2). The DM contents of SS, HMC, and FGC and NDF content of SS were used to adjust diets each week.

\section{Performance Traits}

Bulls were weighed 5 times during the experiment without shrink. Rate of gain was determined by linear regression of full BW over time (Ferreiro and Preston, 1976). On d 46 and 74 of the feeding period, fecal samples were collected directly from the rectum of each animal. A blood sample from each bull was collected using jugular venipuncture on d 74 to measure blood lactate and $\mathrm{pH}$ using an i-STAT Clinical Analyzer with CG4+ cartridges (i-STAT Corp., Princeton, NJ).

After $81 \mathrm{~d}$ from the start of adaptation, bulls were harvested in a commercial abattoir located $132 \mathrm{~km}$ from the feedlot. Shrunk BW was calculated as final BW $\times 0.96$. Estimates of the percentage of renal, pelvic, and inguinal fats were obtained from the left half of carcass and HCW (without internal organs and kidney and pelvic fats) was determined as the sum of weights for the 2 carcass halves. Livers were weighed and incidence and severity of liver 
Table 2. Composition (DM basis) of sugarcane silage (SS), high-moisture flint corn (HMC), and finely ground dry flint corn (FGC)

\begin{tabular}{lrrr}
\hline \hline Composition, \% & $\mathrm{SS}^{1}$ & $\mathrm{HMC}^{1}$ & $\mathrm{FGC}^{1}$ \\
\hline $\mathrm{DM}$ & 25.04 & 60.12 & 87.30 \\
$\mathrm{CP}$ & 4.18 & 7.60 & 9.48 \\
Ether extract & 1.46 & 4.58 & 3.31 \\
NDF & 64.01 & 8.40 & 12.95 \\
ADF & 43.58 & 3.43 & 3.91 \\
Lignin & 7.39 & 1.69 & 1.03 \\
Ash & 3.31 & 0.86 & 1.46 \\
Starch & - & 72.40 & 66.75 \\
\hline
\end{tabular}

${ }^{1}$ One composite sample of each ingredient was analyzed.

abscesses were determined (Brown et al., 1975). Weight of each rumen was measured and incidence of ruminitis was scored (Bigham and McManus, 1975).

Twenty-four hours after slaughter, the left sides of 7 carcasses randomly selected from each treatment were sectioned in the region between the 12th and 13th ribs to obtain digital images of the LM surface for measurement of LM area and subcutaneous fat thickness using the software Lince (M\&S Consultoria Ltda, Pirassununga, SP, Brazil).

\section{Sample Analyses}

The vitreousness of the corn starch was $77.2 \pm$ $5.5 \%$ based on dissection of 100 kernels (DombrinkKurtzman and Bietz, 1993). Mean particle size of HMC $(n=3)$ and FGC $(n=3)$ was evaluated using methods adapted from Yu et al. (1998; Table 3). For the particle size of the SS $(n=2)$ and the complete diets $(n=4$ each), the Penn State Particle Size Separator was used (Lammers et al., 1996), with 1 additional sieve with a 1.18 -mm pore size (Table 4 ).

Samples of total diets, orts, and ingredients were dried at $55^{\circ} \mathrm{C}$, ground in a Wiley mill using a $1-\mathrm{mm}$ screen before forming a composite sample, and then analyzed for chemical composition; TDN values were estimated (Weiss et al., 1992). Maintenance energy requirements (Lofgreen and Garrett, 1968) were calculated and multiplied by a correction factor of 0.9 for Bos indicus breeds (NRC, 1996); energy gain (NRC, 1984) was calculated to estimate the NEm and NEg that bulls obtained from their diets (Zinn and Shen, 1998). The NEg was used to calculate ME (NRC, 1996); total ME intake thereby was estimated. Samples were analyzed for DM, ash, and ether extract (934.01, 942.05, 920.29; AOAC, 1995); CP (Leco nitrogen analyzer, FP-528; Leco Corp., St. Joseph, MI); NDF, ADF, and lignin (Van Soest et al., 1991); NDIN and ADIN (Licitra et al., 1996); and starch (Knudsen, 1997). Concentrations of NDF were deter-
Table 3. Characterization of particle size distribution of high-moisture flint corn (HMC) and finely ground dry flint corn (FGC)

\begin{tabular}{lrrrrrrrr}
\hline \hline & \multicolumn{7}{c}{ Screen mesh size, mm } & \\
\cline { 2 - 7 } & 4.00 & 2.00 & 1.00 & 0.84 & 0.42 & 0.25 & $<0.25$ & MPS, ${ }^{1}$ \\
\cline { 2 - 7 } Item & \multicolumn{7}{c}{ Percent retained } & \\
\hline HMC & 95.58 & 2.72 & 1.44 & 0.28 & 0.29 & 0.19 & 0.00 & 5.84 \\
FGC & 0.11 & 7.04 & 60.53 & 3.74 & 17.27 & 6.81 & 6.04 & 1.30 \\
\hline
\end{tabular}

${ }^{1}$ MPS $=$ mean particle size. Mean particle size of 3 samples of HMC and FGC were evaluated using methods adapted from Yu et al. (1998), with removal of the $0.60-\mathrm{mm}$ sieve porosity and replacement of 0.85 - and $0.43-\mathrm{mm}$ porosity sieves with 0.84 - and $0.42-\mathrm{mm}$ sieves.

mined using $\alpha$-amylase (Termamyl 120L; Novozymes, Bagsvaerd, Denmark) and sodium sulfite.

Fecal densities were measured before samples were dried at $55^{\circ} \mathrm{C}$ and ground in a Wiley mill using a 1-mm screen. The fecal samples were analyzed for DM (934.01; AOAC, 1995) and starch content was estimated by near-infrared reflectance spectroscopy (NIRSystem 5000; Foss NIRSystems Inc., Silver Spring, MD) using an equation developed by Caetano et al. (2009). Fecal $\mathrm{pH}$ was measured following the method suggested by Haaland et al. (1982) as adapted by Channon et al. (2004). Corn NEm (NEm corn $_{\text {) }}$ and corn NEg ( $\left.\mathbf{N E g}_{\text {corn }}\right)$ also were estimated from fecal starch (FS) as described by Zinn et al. (2002).

\section{Statistical Analysis}

Performance data, blood measures, carcass characteristics, and fecal parameters were analyzed using the MIXED procedure (SAS Inst. Inc., Cary, NC). Corn processing, rNDF concentration in the diet, sampling

Table 4. Characterization of particle size distribution of sugarcane silage (SS) and experimental diets containing either high-moisture flint corn (HMC) or finely ground dry flint corn (FGC)

\begin{tabular}{lcccccc}
\hline \hline & & \multicolumn{5}{c}{ Screen mesh size, mm } \\
\cline { 3 - 5 } & rNDF, ${ }^{2}$ & 19 & 8 & 1.18 & $<1.18$ & MPS, ${ }^{2}$ \\
\cline { 3 - 5 } Item & $\%$ & \multicolumn{5}{c}{ Percent retained } \\
\hline SS & - & 9.28 & 57.40 & 25.07 & 8.12 & 1.08 \\
HMC & 3 & 7.90 & 42.62 & 38.30 & 11.18 & 0.85 \\
& 8 & 7.67 & 48.66 & 33.78 & 9.90 & 0.92 \\
& 13 & 7.28 & 50.30 & 32.29 & 10.03 & 0.94 \\
& 18 & 7.06 & 50.00 & 30.91 & 12.03 & 0.93 \\
FGC & 3 & 6.79 & 21.57 & 27.24 & 44.40 & 0.69 \\
& 8 & 6.81 & 23.09 & 29.59 & 40.52 & 0.69 \\
& 13 & 7.32 & 29.77 & 32.32 & 30.60 & 0.75 \\
& 18 & 7.28 & 33.51 & 33.58 & 25.64 & 0.78 \\
\hline
\end{tabular}

${ }^{1} \mathrm{rNDF}=\mathrm{NDF}$ from roughage.

${ }^{2} \mathrm{MPS}=$ mean particle size. Mean particle size of 2 samples of the SS and 4 samples of each diet were evaluated using the Penn State Particle Size Separator (Lammers et al., 1996) with 1 additional sieve with a 1.18-mm pore size. 
Table 5. Effects of corn processing method (CPM) and NDF from roughage (rNDF), and the interaction between $\mathrm{CPM}$ and rNDF on performance of Nellore type bulls

\begin{tabular}{|c|c|c|c|c|c|c|c|c|c|c|c|c|c|c|}
\hline \multirow[b]{3}{*}{ Item } & \multicolumn{4}{|c|}{ High-moisture corn } & \multicolumn{4}{|c|}{ Finely ground dry corn } & \multirow[b]{3}{*}{ SEM } & \multirow{2}{*}{\multicolumn{5}{|c|}{$P$-value }} \\
\hline & \multicolumn{8}{|c|}{$\mathrm{rND} F, \%$} & & & & & & \\
\hline & 3 & 8 & 13 & 18 & 3 & 8 & 13 & 18 & & CPM & rNDF & Linear & Quadratic & $\mathrm{CPM} \times \mathrm{rNDF}$ \\
\hline Initial BW, kg & 380.3 & 378.6 & 382.6 & 378.25 & 374.6 & 385.2 & 380.3 & 386.6 & 15.65 & 0.64 & 0.77 & - & - & 0.47 \\
\hline Final BW, kg & 478.4 & 494.1 & 518.5 & 492.2 & 479.7 & 500.7 & 507.0 & 510.3 & 13.21 & 0.52 & $<0.01$ & $<0.01$ & $<0.01$ & 0.31 \\
\hline $\mathrm{ADG}, \mathrm{kg} / \mathrm{d}$ & 1.22 & 1.42 & 1.62 & 1.39 & 1.28 & 1.42 & 1.56 & 1.51 & 0.09 & 0.65 & $<0.01$ & $<0.01$ & 0.01 & 0.73 \\
\hline G:F & 0.166 & 0.179 & 0.180 & 0.165 & 0.145 & 0.140 & 0.159 & 0.160 & 0.01 & $<0.01$ & 0.38 & - & - & 0.25 \\
\hline $\mathrm{NEm}, \mathrm{Mcal} / \mathrm{kg}$ & 2.00 & 2.06 & 2.03 & 1.93 & 1.74 & 1.70 & 1.84 & 1.87 & 0.06 & $<0.01$ & 0.68 & - & - & 0.08 \\
\hline NEg, Mcal, kg & 1.34 & 1.40 & 1.37 & 1.28 & 1.12 & 1.08 & 1.20 & 1.23 & 0.05 & $<0.01$ & 0.68 & - & - & 0.08 \\
\hline ME, Mcal $/ \mathrm{kg}$ & 2.96 & 3.04 & 3.01 & 2.88 & 2.65 & 2.60 & 2.76 & 2.80 & 0.07 & $<0.01$ & 0.71 & - & - & 0.08 \\
\hline ME intake, Mcal/d & 21.91 & 24.21 & 27.34 & 24.27 & 23.74 & 26.42 & 27.26 & 26.61 & 0.96 & 0.02 & $<0.01$ & $<0.01$ & $<0.01$ & 0.55 \\
\hline
\end{tabular}

period (only for fecal traits), and first-, second-, and third-order interactions were used as fixed effects; block (initial BW) was included as a random effect, and animal was the experimental unit. Treatment means were determined using the LSMEANS statement. Nonparametric binomial proportional data of ruminitis score and liver abscess were analyzed using the GLIMMIX procedure (SAS Inst. Inc.) with the same overall model described above. When significant effects of rNDF concentrations were observed, optimal rNDF concentrations were estimated using the first derivative of second order polynomial regression equations. For analysis of correlation between FS content and other parameters, the CORR procedure was used (SAS Inst. Inc.). Tests for fixed effects with $P \leq 0.05$ were declared significant and those with $P>0.05$ and $P \leq 0.10$ were considered a tendency.

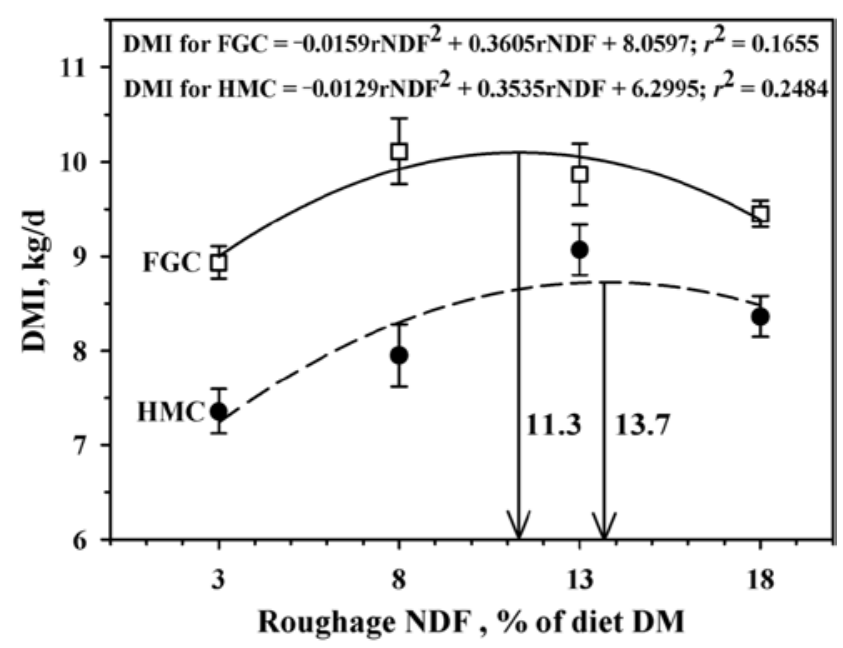

Figure 1. Interaction between grain processing (high-moisture flint corn $[\mathrm{HMC}]$ and finely ground dry flint corn $[\mathrm{FGC}])$ and NDF from roughage (rNDF) for DMI $(P=0.05)$. Vertical bars represent SEM. Vertical lines show the optimal rNDF level estimated using the first derivative of second order polynomial regression equations.

\section{RESULTS}

\section{Performance}

No significant interactions were observed between grain processing and rNDF for performance characteristics except DMI. Initial BW was not different among treatments (Table 5), and final BW and ADG were not affected by grain processing method.

An interaction between CPM and rNDF was observed for DMI $(P=0.05)$. When bulls were fed HMC, DMI was optimized at $13.7 \%$ rNDF, but when bulls were fed FGC, optimum rNDF level was $11.3 \%$ (Fig. 1). The requirement of rNDF for maximum DMI for HMC was $21.2 \%$ higher than with FGC; however, DMI for bulls fed HMC was $14.6 \%$ less than for bulls fed FGC and presumably is attributable to differences in grain processing methods. Bulls fed HMC had 13.9\% greater G:F compared with bulls fed FGC $(P<0.01)$.

Dietary NEm and NEg (Mcal $/ \mathrm{kg}$ ) were 12.3 and $16.4 \%$ greater, respectively, for bulls fed HMC in comparison to bulls fed FGC $(P<0.01)$. Similarly, ME was greater for bulls fed HMC compared with bulls fed FGC $(P<0.01)$. The HMC diets had $9.6 \%$ more ME per kilogram of diet than FGC $(P<0.01)$. On the other hand, ME intake (Mcal/d) was $6.1 \%$ less for bulls fed HMC $(P=0.02)$ compared with those fed FGC. Increased DMI by bulls fed FGC can be ascribed to the lower availability of energy when compared with HMC.

Final BW was quadratically impacted in response to $\mathrm{rNDF}$ concentration (final $\mathrm{BW}=-0.2951 \mathrm{rNDF}^{2}+$ 7.8579rNDF $\left.+457.0700 ; r^{2}=0.12, P<0.01\right)$, with the greatest final BW estimated to occur at $13.3 \%$ rNDF. Similarly, quadratic regression equations indicated that the greatest ADG was achieved with $13.0 \% \mathrm{rNDF}$ $\left(\mathrm{ADG}=-0.0031 \mathrm{rNDF}^{2}+0.0803 \mathrm{rNDF}+1.0212 ; r^{2}=\right.$ $0.12, P=0.01)$. The $13 \% \mathrm{rNDF}$ for ADG was 21.4 , 10.7 , and $8.8 \%$ greater compared with treatments containing 3,8 , and $18 \%$ rNDF, respectively. The level 
Table 6. Effects of corn processing method (CPM), NDF from roughage (rNDF), and the interaction between CPM and rNDF on starch content of Nellore type bulls

\begin{tabular}{|c|c|c|c|c|c|c|c|c|c|c|c|c|}
\hline \multirow[b]{3}{*}{ Item } & \multicolumn{4}{|c|}{ High-moisture corn } & \multicolumn{4}{|c|}{ Finely ground dry corn } & \multirow[b]{3}{*}{ SEM } & \multirow{2}{*}{\multicolumn{3}{|c|}{$P$-value }} \\
\hline & \multicolumn{8}{|c|}{ rNDF, $\%$} & & & & \\
\hline & 3 & 8 & 13 & 18 & 3 & 8 & 13 & 18 & & $\mathrm{CPM}$ & rNDF & $\mathrm{CPM} \times \mathrm{rNDF}$ \\
\hline Orts starch, ${ }^{1} \%$ & $59.75^{\mathrm{a}}$ & $53.12^{\mathrm{bc}}$ & $46.36^{\mathrm{d}}$ & $38.80^{\mathrm{e}}$ & $55.18^{\mathrm{b}}$ & $51.00^{\mathrm{c}}$ & $48.09^{\mathrm{d}}$ & $39.43^{\mathrm{e}}$ & 0.98 & 0.12 & $<0.01$ & $<0.01$ \\
\hline Starch intake, ${ }^{1} \%$ & $55.12^{\mathrm{a}}$ & $50.25^{\mathrm{c}}$ & $45.19^{d}$ & $42.74^{\mathrm{e}}$ & $51.11^{b}$ & $50.58^{\mathrm{c}}$ & $40.16^{\mathrm{f}}$ & $36.73^{\mathrm{g}}$ & 0.18 & $<0.01$ & $<0.01$ & $<0.01$ \\
\hline Fecal pH, d 46 & 7.14 & 7.42 & 7.35 & 7.60 & 6.56 & 6.61 & 6.72 & 6.74 & 0.18 & $<0.01$ & 0.35 & 0.83 \\
\hline Fecal pH, d 74 & 5.58 & 5.75 & 5.74 & 5.73 & 5.73 & 5.86 & 5.79 & 5.88 & 0.11 & 0.13 & 0.50 & 0.97 \\
\hline Fecal DM, \% & $17.10^{\mathrm{cd}}$ & $14.65^{\text {ef }}$ & $13.11^{\mathrm{f}}$ & $13.72^{\mathrm{f}}$ & $22.93^{\mathrm{a}}$ & $19.34^{\mathrm{b}}$ & $17.74^{\mathrm{bc}}$ & $15.53^{\text {de }}$ & 0.73 & $<0.01$ & $<0.01$ & $<0.01$ \\
\hline Fecal density, $\mathrm{g}$ of $\mathrm{OM} / \mathrm{mL}$ & 1.117 & 1.102 & 1.089 & 1.114 & 1.132 & 1.118 & 1.129 & 1.124 & 0.01 & $<0.01$ & 0.17 & 0.25 \\
\hline $\mathrm{NEm}_{\text {corn }},{ }^{2} \mathrm{Mcal} / \mathrm{kg}$ & $2.43^{\mathrm{ab}}$ & $2.45^{\mathrm{ab}}$ & $2.46^{\mathrm{a}}$ & $2.45^{\mathrm{ab}}$ & $2.14^{\mathrm{d}}$ & $2.19^{\mathrm{d}}$ & $2.28^{\mathrm{c}}$ & $2.38^{\mathrm{b}}$ & 0.03 & $<0.01$ & $<0.01$ & $<0.01$ \\
\hline $\mathrm{NEg}_{\text {corn }},{ }^{3} \mathrm{Mcal} / \mathrm{kg}$ & $1.72^{\mathrm{ab}}$ & $1.74^{\mathrm{ab}}$ & $1.75^{\mathrm{a}}$ & $1.74^{\mathrm{ab}}$ & $1.47^{\mathrm{d}}$ & $1.51^{\mathrm{d}}$ & $1.59^{\mathrm{c}}$ & $1.67^{\mathrm{b}}$ & 0.03 & $<0.01$ & $<0.01$ & $<0.01$ \\
\hline
\end{tabular}

of rNDF that maximizes ADG and final BW was very close to the level required for maximum DMI.

The G:F, NEm, NEg, and ME were not affected by increasing level of rNDF in the diet. Metabolizable energy intake was affected by $\operatorname{rNDF}(P<0.01)$, and the quadratic regression showed the optimum level occurred at $12.8 \%$ rNDF $\left(\mathrm{ME}\right.$ intake $=-0.0430 \mathrm{rNDF}^{2}+$ $\left.1.1032 \mathrm{rNDF}+19.7393 ; r^{2}=0.16, P<0.01\right)$.

No interactions between CPM and rNDF were observed for blood constituents. Lactate (data not shown) was numerically greater for bulls fed HMC compared with those fed FGC (3.61 vs. $2.92 \mathrm{mM}$, respectively), but differences were not significant $(P=0.14)$. Blood pH was unaffected by CPM (7.43 vs. 7.44 for bulls fed HMC and FGC, respectively).

Level of rNDF did not affect lactate; however, there was a linear tendency of rNDF to reduce blood $\mathrm{pH}$ with decreasing levels of $\mathrm{rNDF}$ (blood $\mathrm{pH}=$ $0.0023 \mathrm{rNDF}+7.4080 ; r^{2}=0.06, P<0.09$ ). These results may reflect subclinical problems with metabolic disorders for bulls fed the lowest rNDF concentrations.

\section{Starch}

The starch content of orts revealed an interaction between CPM and rNDF $(P<0.01$; Table 6). Decreases in rNDF level resulted in linear increases in the starch content of orts for both HMC (starch content of orts for HMC $=-1.3909 \mathrm{rNDF}+64.1177$; $\left.r^{2}=0.89, P<0.01\right)$ and FGC (starch content of orts for $\mathrm{FGC}=-1.0032 \mathrm{rNDF}+58.9599 ; r^{2}=0.63, P<$ $0.01)$. However, orts from HMC diets had more starch compared with orts from FGC diets (49.51 vs. 48.43\%, respectively). Starch content of orts was greater than that of diets, not only for HMC but also for FGC $(P<$ 0.05 ) except for HMC with $18 \%$ rNDF (less orts starch compared with the dietary starch content; $P<0.01$ ) and HMC with $13 \%$ rNDF and FGC with $8 \%$ rNDF (where no difference between orts starch and dietary starch content was detected). These results suggest the Nellore type cattle select for roughage, particularly when the diets have a high content of concentrate.

Starch intake, when expressed as a percentage of DM, also revealed an interaction between CPM and rNDF $(P<0.01)$. Bulls fed both HMC and FGC consumed diets with a lower starch percent as rNDF of diets increased (starch intake for HMC $=-0.8465 \mathrm{rNDF}+57.2529 ; r^{2}=$ $0.97, P<0.01$; starch intake for $\mathrm{FGC}=-1.0709 \mathrm{rNDF}+$ 55.9356; $\left.r^{2}=0.89, P<0.01\right)$.

Fecal characteristics were not affected by sampling period, except for fecal $\mathrm{pH}$. With the first fecal collection, bulls fed HMC had greater fecal $\mathrm{pH}$ than bulls fed FGC $(P<0.01)$. At the second collection, the difference between $\mathrm{HMC}$ and FGC disappeared $(P=$

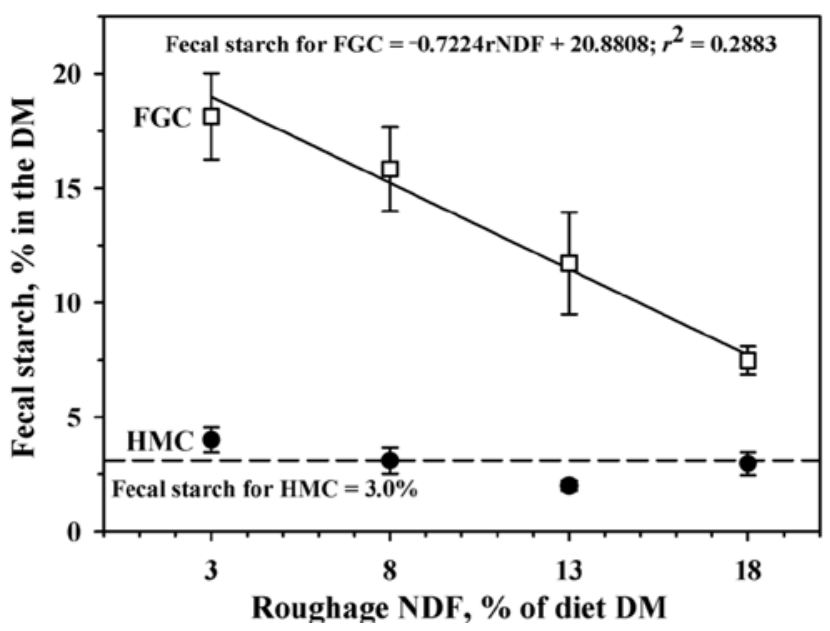

Figure 2. Interaction between grain processing (high-moisture flint corn $[\mathrm{HMC}]$ and finely ground dry flint corn $[\mathrm{FGC}]$ ) and NDF from roughage (rNDF) for fecal starch content $(\mathrm{P}<0.01)$. Vertical bars represent SEM. 
Table 7. Effects of corn processing method (CPM) and NDF from roughage (rNDF), and the interaction between $\mathrm{CPM}$ and rNDF on carcass characteristics of Nellore type bulls

\begin{tabular}{|c|c|c|c|c|c|c|c|c|c|c|c|c|c|c|}
\hline \multirow[b]{3}{*}{ Item } & \multicolumn{4}{|c|}{ High-moisture corn } & \multicolumn{4}{|c|}{ Finely ground dry corn } & \multirow[b]{3}{*}{ SEM } & \multicolumn{5}{|c|}{$P$-value } \\
\hline & \multicolumn{8}{|c|}{ rNDF, $\%$} & & \multirow[b]{2}{*}{$\mathrm{CPM}$} & \multirow[b]{2}{*}{$\mathrm{rNDF}$} & \multirow[b]{2}{*}{ Linear } & \multirow[b]{2}{*}{ Quadratic } & \multirow{2}{*}{$\begin{array}{l}\mathrm{CPM} \times \\
\mathrm{rNDF}\end{array}$} \\
\hline & 3 & 8 & 13 & 18 & 3 & 8 & 13 & 18 & & & & & & \\
\hline $\mathrm{HCW}, \mathrm{kg}$ & 258.0 & 263.9 & 279.6 & 262.8 & 260.1 & 264.0 & 269.7 & 269.0 & 7.81 & 0.92 & 0.01 & 0.04 & 0.04 & 0.37 \\
\hline Dressing, $\%$ & 56.1 & 55.6 & 56.1 & 55.6 & 56.4 & 54.9 & 55.4 & 54.9 & 0.52 & 0.11 & 0.02 & 0.03 & 0.36 & 0.48 \\
\hline $\mathrm{LM}$ area, $\mathrm{cm}^{2}$ & 50.1 & 53.1 & 51.0 & 52.8 & 49.5 & 50.1 & 51.2 & 52.5 & 2.04 & 0.52 & 0.55 & - & - & 0.85 \\
\hline 12th-rib fat, $\mathrm{mm}$ & 3.52 & 3.96 & 3.45 & 3.52 & 2.66 & 3.88 & 3.19 & 3.54 & 0.44 & 0.29 & 0.20 & - & - & 0.69 \\
\hline Renal, pelvic, and inguinal fat, $\mathrm{kg}$ & 3.46 & 3.83 & 4.65 & 3.84 & 3.80 & 4.20 & 4.00 & 4.15 & 0.35 & 0.59 & 0.05 & 0.07 & 0.04 & 0.11 \\
\hline Liver weight, $\mathrm{kg}$ & 5.50 & 5.51 & 5.91 & 5.41 & 5.20 & 5.33 & 5.52 & 5.25 & 0.18 & 0.02 & 0.06 & - & - & 0.88 \\
\hline Liver score, units & 0.28 & 0.14 & 0.00 & 0.23 & 0.00 & 0.00 & 0.07 & 0.00 & 0.12 & 0.08 & 0.81 & - & - & 0.44 \\
\hline Rumen weight, $\mathrm{kg}$ & 9.77 & 9.43 & 9.50 & 9.39 & 8.66 & 9.13 & 9.38 & 9.11 & 0.39 & 0.03 & 0.88 & - & - & 0.36 \\
\hline Ruminitis score, units & 1.68 & 0.11 & 0.25 & 0.67 & 0.40 & 0.33 & 0.25 & 0.18 & 0.36 & 0.08 & 0.03 & 0.07 & 0.02 & 0.08 \\
\hline
\end{tabular}

0.13), but average fecal $\mathrm{pH}$ was lower for both types of corn when compared with the first collection period.

The interaction of CPM and rNDF was significant for FS $(P<0.01$; Fig. 2). Bulls fed HMC had an average FS content of $3.0 \%$, whereas the average for bulls fed FGC was $13.3 \%$. No difference in FS was observed among levels of rNDF for HMC despite the difference in starch intake between treatments. However, FS content linearly decreased as level of rNDF increased in the FGC diets.

An interaction between grain processing method and NDF level also was observed for fecal DM $(P<0.01)$. The fecal DM of bulls fed HMC was 21.5\% lower than those fed the FGC diets. This is consistent with the hypothesis that less starch reached the hindgut in HMC diets to be fermented therein. Increases in the level of rNDF resulted in linear decreases in fecal DM for FGC (fecal $\mathrm{DM}$ for $\mathrm{FGC}=-0.4765 \mathrm{rNDF}+23.8744 ; r^{2}=0.53, P<$ 0.01). However, fecal DM of bulls fed the HMC treatment were not affected by rNDF level except for those fed 3\% rNDF where feces had a higher DM content than the other HMC diets. Density of feces was greater for bulls fed FGC compared with those fed HMC (1.126 vs. $1.107 \mathrm{~g} / \mathrm{mL}$, respectively; $P<0.01$ ).

An interaction between CPM and rNDF also was observed for $\mathrm{NEm}_{\text {corn }}$ and $\mathrm{NEg}_{\text {corn }}$ calculated from $\mathrm{FS}$ $(P<0.01)$. There was no effect of percent rNDF on $\mathrm{NEm}_{\text {corn }}$ or $\mathrm{NEg}_{\text {corn }}$ for bulls fed HMC; however, a linear effect was observed for animals fed FGC $(P<$ 0.01). Therefore, the $\mathrm{NEm}_{\text {corn }}$ and the $\mathrm{NEg}_{\text {corn }}$ in FGC diets increased as more rNDF was included in diets $\left(\mathrm{NEm}_{\text {corn }}\right.$ for $\mathrm{FGC}=0.0159 \mathrm{rNDF}+2.0780 ; r^{2}=0.29$; $\mathrm{NEg}_{\text {corn }}$ for $\mathrm{FGC}=0.0140 \mathrm{rNDF}+1.4126 ; r^{2}=0.29$ ). Values for $\mathrm{NEm}_{\text {corn }}$ and $\mathrm{NEg}_{\text {corn }}$ reflect results similar to FS, because these values are calculated from FS.

Correlations between FS and fecal DM $(r=0.83$, $P<0.01)$, fecal density $(r=0.38, P<0.01)$, and fecal $\mathrm{pH}$ at the first sampling period were detected $(r=$ $-0.61, P<0.01)$.

\section{Carcass Characteristics}

No significant interactions between CPM and rNDF with respect to carcass characteristics were detected (Table 7). The CPM did not affect HCW, dressing percentage, LM area, 12th-rib fat, or percentage of renal, pelvic, and inguinal fat. Liver and rumen weights were affected only by CPM, with liver $(P=$ $0.02)$ and rumen weights $(P=0.03)$ being about $5 \%$ heavier for bulls fed HMC.

Liver scores tended to be affected by CPM ( $P=$ 0.08). Five bulls fed HMC had liver abscesses: 1 with the $18 \%$ rNDF diet (A+ score), 2 with the $8 \%$ rNDF $\operatorname{diet}$ (both A-score), and 2 with the $3 \%$ rNDF diet (1 Aand $1 \mathrm{~A}+$ ) compared with only 1 bull with a liver score of A- when fed FGC and 13\% rNDF (data not shown).

Bulls fed HMC had a tendency $(P=0.08)$ to develop more ruminitis and parakeratosis compared with their counterparts fed FGC (12 vs. 6 bulls; data not shown). For bulls HMC with 3\% rNDF, 7 had ruminitis and parakeratosis, which is half of the bulls fed that diet. With other diets, no more than 2 animals exhibited ruminitis and parakeratosis, and the cases also were less severe.

For $\mathrm{HCW}$, optimum rNDF was $12.8 \%(\mathrm{HCW}=$ $-0.1352 \mathrm{rNDF}^{2}+3.4710 \mathrm{rNDF}+248.6800 ; r^{2}=0.06$, $P=0.04)$. This is similar to the dietary fiber level that optimized ME intake.

A quadratic effect of rNDF on the percentage of renal, pelvic, and inguinal fat $(P=0.05)$ was detected; inclusion of $12.6 \%$ rNDF maximized fat (renal, pelvic, and inguinal fat $=-0.0070 \mathrm{rNDF}^{2}+0.1764 \mathrm{rNDF}+$ $\left.3.1356 ; r^{2}=0.06\right)$. No significant effects of rNDF level on for LM area or 12th-rib fat were detected.

Ruminitis score was affected by $\operatorname{rNDF}(P=0.03)$. The lowest incidence of ruminitis and parakeratosis occurred at $12.4 \% \mathrm{rNDF}$ (ruminitis score $=0.0098 \mathrm{rNDF}^{2}$ $\left.-0.2435 \mathrm{rNDF}+1.6415 ; r^{2}=0.07, P=0.02\right)$. Liver abscess score was not affected by rNDF level $(P=0.81)$. 


\section{DISCUSSION}

\section{Performance and Carcass Characteristics}

Including between 10 and $15 \%$ of roughage in the total mixed ration (DM basis) appears necessary to maintain health of the ruminal epithelium (Wise et al., 1968). However, considering the high cost per unit of energy and extra effort in handling roughage, nutritionists commonly provide the minimum roughage level that allows adequate animal performance (Zinn et al., 2004). Gill et al. (1981) evaluated 5 roughage levels $(8,12,16,20$, and $24 \%$ of diet DM) using a mixture of alfalfa and corn silage (1:2 on DM basis). They suggested that roughage levels of 8,12 , and $16 \%$ were needed to optimize ADG and $\mathrm{G}: \mathrm{F}$ in diets that used steam-flaked corn, a 50:50 mixture (steam-flaked:high-moisture corn), and high-moisture corn, respectively. Alvarez et al. (2004) suggested that levels of rNDF in the finishing diets should be between 6 and $9 \%$; including less than $6 \%$ rNDF depressed energy intake and $\mathrm{ADG}$, whereas diets that contained more than $9 \%$ rNDF often limited energy intake and ADG due to excessive ruminal fill. In the present experiment, despite low coefficients of determination observed, approximately $13 \%$ rNDF yielded optimal results for final BW, $\mathrm{ADG}, \mathrm{HCW}$, ruminitis score, and renal, pelvic, and inguinal fat. Moreover, ME intake and $\mathrm{HCW}$ were greater with $12.8 \%$ of rNDF. Because cattle owners typically are paid on the basis of HCW, and because the same level of rNDF was found for ME intake that showed one of the greatest variance accounted by rNDF level, the optimum carcass value in the present study would be achieved with $12.8 \%$ rNDF. When Brahman steers were fed diets containing high, medium, and low energy, the digestible DM intakes did not differ. However, with Bos taurus steers fed these same diets, digestible DM increased with each increase in energy level (Moore et al., 1975). Another study showed the same ADG $(1.19 \mathrm{~kg} / \mathrm{d})$ for Brahman cattle fed with 60 or $15 \%$ of corn silage in the total mixed ration (Olbrich, 1996). Leme et al. (2003) did not find any difference in final BW, ADG, and G:F for Nellore steers fed 15, 21, and 27\% sugarcane bagasse in the total mixed ration (DM basis), but the DMI was decreased with the highest level of bagasse sugarcane. This reduction in DMI was associated with the high NDF content of sugarcane bagasse and low roughage quality that presumably exceeded the physical limits of the rumen. Several trials have shown that DMI linearly increases (Gill et al., 1981; Kreikemeier et al., 1990; Hales et al., 2010; MacDonald et al., 2011) as DM and OM digestibility of the diet decreases as diet forage content increases. However, all these trials included up to $15 \%$ of forage (DM basis) in the total mixed ration. Gill et al. (1981) included $8,12,16,20$, and 24\% (DM basis) of alfalfa hay (one-third) and corn silage (two-thirds) mixture with different CPM (HMC, steam flaked, and a 50:50 mixture). These authors also observed that DMI linearly increased with increased forage in the diet. Forage level in their diets was lower when compared with the $18 \%$ rNDF used in the current study.

In the present study, the rNDF level for maximum DMI differed between FGC and HMC. A higher roughage inclusion was necessary for the HMC. Greater dietary roughage level decreased DMI in another trial with Nellore steers fed diets with 9 and $27 \%$ of DM from corn silage (Nuñez et al., 2013). These authors observed that DMI, ME intake, and ADG all were lower for animals fed diets with $27 \%$ corn silage than for animals fed diets with $9 \%$ corn silage. This reduced DMI by animals fed more roughage can be explained by increased physical fill associated with higher NDF content of the diet, as was observed in our study for bulls fed $18 \%$ rNDF ( $27.8 \%$ of SS). In the present study, even low inclusion of rNDF reduced DMI, presumably due to greater availability of starch, which met the physiological energy demands of bulls and thus depressed intake. Consistent with energy intake limitation, HMC often decreases DMI and improves G:F with little change in ADG (Silva et al., 2007).

\section{Energy}

Even with low rNDF, decreases in feed intake sometimes exceed the increase in energy digestibility, thereby resulting in decreased ME intakes and ADG. This is often associated with very low fiber diets or with highly digestible starch sources. In the present study, lower energy intake and daily gain were observed for the $3 \%$ rNDF and may have been the consequence of subclinical or clinical metabolic disturbances.

According to the NRC (1996), NEm and NEg are 2.33 and $1.62 \mathrm{Mcal} / \mathrm{kg}$ for HMC, respectively, and 2.18 and $1.50 \mathrm{Mcal} / \mathrm{kg}$ for ground corn, respectively. Therefore, the NRC for estimates NEm and NEg are 6.9 and 8.0\% greater, respectively, for HMC than for finely ground corn. Based on performance of bulls in the present study, NEm and NEg were 12.3 and $16.4 \%$ greater, respectively, for steers fed HMC than for those fed FGC. Greater than expected response may be related to the texture of the flint corn in this trial; most data used by the NRC relates to dent, not flint, corn. Furthermore, NRC values may be underestimated for processed corn, a claim that has some support in the literature (Zinn et al., 2002).

In the current study, dietary NEm and NEg calculated from performance were not affected by rNDF (Table 5). This can be explained by an increased incidence of metabolic problems with low rNDF diets. Also, zebu animals may have greater FS loss with low NDF 
diets. Kreikemeier et al. (1990) fed steam-rolled wheat to British breed and crossbred steers and observed a quadratic effect of roughage on NEm and NEg for diets with $0,5,10$, and $15 \%$ of alfalfa hay. Parsons et al. (2007), using NRC (1996) equations, observed that NEm and NEg linearly increased as alfalfa hay level decreased with a steam-flaked corn-based diet fed to crossbred steers (Brangus and Angus). May et al. (2011) evaluated British crossbred fed a steam-flaked corn-based diet with 3 inclusion levels of alfalfa hay $(7.5,10$, and $12.5 \%$ of $\mathrm{DM}$ ) and wet distillers grains with solubles (15 and 30\%). These authors observed that NEm and NEg calculated from performance data increased when dietary roughage was reduced. In the present study, estimated ME intake, calculated from dietary NEg, was affected by $\mathrm{rNDF}(P<$ 0.01 ), with the highest ME intake being at $12.8 \%$ rNDF.

Bulls fed HMC had lower ME intake than bulls fed FGC, because although DMI was reduced, ME per kilogram of diet was greater for HMC. The greater ME content for HMC over FGC diets may explain the higher rumen and liver weight. Even though rumen and liver are the organs responsible for the most of the energy expended by cattle (Baldwin, 1995), efficiency of bulls fed HMC, based on NEg, was not affected.

\section{Liver and Ruminitis}

Liver score and blood lactate did not differ among treatments. Differences were expected as the use of older aged animals, the shorter finishing period, and the type of pens (individual feeding or small pens) may be responsible. Having a less developed immune system, younger cattle may be more susceptible to ruminitis and bacterial infection. Animals in the present study were 24 to $36 \mathrm{mo}$ of age. Animals fed finishing diets for a longer period are more likely to exhibit acidosis, ruminitis, and liver abscesses, but in Brazil, most feedlots feed concentrate diets for only a relatively short period, similar to the duration of feeding used in this trial. Moreover, cattle housed in collective pens may have a higher incidence of liver abscess than those in individual pens due competition for feed. Rumen abnormalities may be the variable associated most closely with low performance in Bos indicus fed high grain basis diets for a short period of time. Ruminitis scores for bulls fed 3\% rNDF had a greater incidence of ruminitis/parakeratosis, and this is supported by blood $\mathrm{pH}$ values.

\section{Starch}

Our data are consistent with the suggestion that HMC has greater total tract starch digestibility (Owens et al., 1986; Cooper et al., 2002) compared with FGC, because FS content was lower for HMC than FGC. This reflects breakdown of the protein matrix in the endosperm of HMC or the fact that it is not fully consolidated at harvest. In addition, the $\mathrm{HMC}$ was allowed to ferment in a silo for 6 mo. Extending ensiling time increases the degradation of hydrophobic zein proteins in the starchprotein matrix in vitro (Hoffman et al., 2011). Increases in starch digestibility in the rumen were expected with HMC diets, but with HMC, more forage (around 13\% of $\mathrm{rNDF}$ ) was required to promote rumen health.

More vitreous corn dry kernels usually have lower in situ ruminal starch degradation (Philippeau et al., 1999; Correa et al., 2002). However, vitreousness is altered by corn processing. Fecal starch content is useful as a tool to estimate total tract starch digestibility (Zinn et al., 2002). When sources of corn differing in vitreousness were steam flaked, FS contents (\% of DM) were unaffected by grain vitreousness; however, when dry-rolled corn was fed, FS percentage increased as grain vitreousness increased (Corona et al., 2006). In the present study, the high vitreousness of the Brazilian flint corn did not affect the digestibility of HMC, because the FS content remained quite low and was similar among HMC diets $(3.0 \%$ of DM). This suggests the ensiling eliminated vitreousness differences, similar to the effects noted with steam flaking (Owens and Zinn, 2005). On the other hand, fine grinding of dry corn did not overcome effects of grain vitreousness because the average loss of starch in feces was much higher (13.3\% of DM) and when flint corn content of the diet increased, FS content increased. Ensiling increased starch availability.

\section{Physically Effective NDF}

The rNDF requirements for Nellore type bulls discussed above are based only on SS. However, diet DM also contained $8 \%$ WLC. Whole cottonseed is a nonforage fiber source used most commonly in Brazil as a source of protein and fat but also can be used to replace roughage. Clark and Armentano (1993) compared WLC to alfalfa haylage with mean particle length of 7.6 $\mathrm{mm}$ and determined that effective NDF content of the WLC was 1.3 times that of the haylage. Mooney and Allen (1997) estimated physical effectiveness of NDF in WLC to be 50 and $127 \%$ that of alfalfa silage cut long $(11.4 \mathrm{~mm})$ or short $(5.8 \mathrm{~mm})$, respectively. Sugarcane silage in the present study was cut at particle length of $10.8 \mathrm{~mm}$. Therefore, we estimated that the NDF effectiveness factor of WLC was 0.50 in the present study. The NDF content of WLC was 43.04\% (DM basis), suggesting that diets without WLC should contain an additional $1.7 \%$ rNDF beyond the rNDF from SS to achieve the optimal performance of Nellore type bulls. 
The performance of Nellore type bulls was optimum at $12.8 \%$ rNDF when fed high-concentrate diets based on flint corn with $8 \%$ whole cottonseeds. Because the diets fed contained cottonseed, we estimate that performance should be optimized with about $14.5 \%$ rNDF without cottonseeds.

\section{LITERATURE CITED}

Alvarez, E. G., J. F. Calderon, M. F. Montano, R. A. Ware, and R. A. Zinn. 2004. Influence of dietary forage level on digestive function and growth performance in cattle fed steamflaked corn-based growing-finishing diets. J. Anim. Vet. Adv. 3:506-512. doi:javaa.2004.506.512.

AOAC. 1995. Official methods of analysis. 16th ed. AOAC Int., Washington, DC.

Baldwin, R. L. 1995. Modeling ruminant digestion and metabolism. 1st ed. Chapman and Hall, London, UK.

Bigham, M. L., and W. R. McManus. 1975. Whole wheat grain feeding of lambs. V. Effects of roughage and wheat grain mixtures. Aust. J. Agric. Res. 26:1053-1062. doi:10.1071/AR9751053.

Brown, H., R. F. Bing, H. P. Grueter, J. W. McAskill, C. O. Cooley, and R. P. Rathmacher. 1975. Tylosin and chlortetracycline for the prevention of liver abscesses, improved weight gains and feed efficiency in feedlot cattle. J. Anim. Sci. 40:207-213.

Caetano, M., C. M. Bittar, and D. P. D. Lanna. 2009. Desenvolvimento de equações para predição do teor de amido fecal de bovinos por espectroscopia de reflectância do infravermelho próximo (NIRS). In: Proc. 46th Soc. Bras. Zootec., Maringá, Brazil. (In portuguese.) CD-ROM.

Channon, A. F., J. B. Rowe, and R. M. Herd. 2004. Genetic variation in starch digestion in feedlot cattle and its association with residual feed intake. Aust. J. Exp. Agric. 44:469-474. doi:10.1071/EA02065.

Clark, P. W., and L. E. Armentano. 1993. Effectiveness of neutral detergent fiber in whole cottonseed and dried distillers grains compared with alfalfa haylage. J. Dairy Sci. 76:2644-2650. doi:10.3168/jds.S0022-0302(93)77600-6.

Cooper, R. J., C. T. Milton, T. J. Klopfenstein, T. L. Scott, C. B. Wilson, and R. A. Mass. 2002. Effect of corn processing on starch digestion and bacterial crude protein flow in finishing cattle. J. Anim. Sci. 80:797-804.

Corona, L., F. N. Owens, and R. A. Zinn. 2006. Impact of corn vitreousness and processing on site and extent of digestion by feedlot cattle. J. Anim. Sci. 84:3020-3031. doi:10.2527/jas.2005-603.

Correa, C. E. S., R. D. Shaver, M. N. Pereira, J. G. Lauer, and K. Kohn. 2002. Relationship between corn vitreousness and ruminal in situ starch degradability. J. Dairy Sci. 85:3008-3012. doi:10.3168/jds.S0022-0302(02)74386-5.

Cruz, J. C., L. R. Queiroz, and I. A. Pereira Filho. 2012. Mais de 210 cultivares transgênicas são disponibilizadas no mercado de sementes do Brasil para a safra 2012/13. (In portuguese.) http://www.apps.agr.br/upload/ax10_3007201206195700 cultivaresdemilhoparaasafra2012_2013.pdf. (Accessed $2 \overline{6}$ April 2015.)

Dombrink-Kurtzman, M. A., and J. A. Bietz. 1993. Zein composition in hard and soft endosperm of maize. Cereal Chem. 70:105-108.

Ferreiro, H. M., and T. R. Preston. 1976. Fattening cattle with sugar cane: The effect of different proportions of stalk and tops. http://www.utafoundation.org/UTAINFO1/TAP/ TAP13/1_3_4.pdf. (Accessed 26 April 2015.)

Galyean, M. L., and P. J. Defoor. 2003. Effects of roughage source and level on intake by feedlot cattle. J. Anim. Sci. 81:E8-E16.
Gill, D. R., F. N. Owens, J. J. Martin, D. E. Williams, R. A. Zinn, and R. J. Hillier. 1981. Roughage levels in feedlot rations. Res. Reprod. MP-108:141-146. Oklahoma Agric. Exp. Stn., Stillwater, OK.

Haaland, G. L., H. F. Tyrrell, P. W. Moe, and W. E. Wheeler. 1982. Effect of crude protein level and limestone buffer in diets fed at two levels of intake on rumen $\mathrm{pH}$, ammonia-nitrogen, buffering capacity and volatile fatty acid concentration of cattle. J. Anim. Sci. 55:943-950.

Hales, K. E., J. P. McMeniman, J. Leibovich, J. T. Vasconcelos, M. J. Quinn, M. L. May, N. DiLorenzo, D. R. Smith, and M. L. Galyean. 2010. Effects of varying bulk densities of steam-flaked corn and dietary roughage concentration on in vitro fermentation, performance, carcass quality, and acidbase balance measurements in finishing steers. J. Anim. Sci. 88:1135-1147. doi:10.2527/jas.2009-2400.

Hoffman, P. C., N. M. Esser, R. D. Shaver, W. K. Coblentz, M. P. Scott, A. L. Bodnar, R. J. Schmidt, and R. C. Charley. 2011. Influence of ensiling time and inoculation on alteration of the starch-protein matrix in high-moisture corn. J. Dairy Sci. 94:2465-2474. doi:10.3168/jds.2010-3562.

Knudsen, K. E. B. 1997. Carbohydrate and lignin contents of plant materials used in animal feeding. Anim. Feed Sci. Technol. 67:319-338. doi:10.1016/S0377-8401(97)00009-6.

Kreikemeier, K. K., D. L. Harmon, R. T. Brandt Jr., T. G. Nagaraja, and R. C. Cochran. 1990. Steam-rolled wheat diets for finishing cattle: Effects of dietary roughage and feed intake on finishing steer performance and ruminal metabolism. J. Anim. Sci. 68:2130-2141.

Lammers, B. P., D. R. Buckmaster, and A. J. Heinrichs. 1996. A simple method for the analysis of particle sizes of forage and total mixed rations. J. Dairy Sci. 79:922-928. doi:10.3168/ jds.S0022-0302(96)76442-1.

Leme, P. R., S. L. Silva, A. S. C. Pereira, S. M. Putrino, D. P. D. Lanna, and J. C. M. Nogueira Filho. 2003. Utilização do bagaço de cana-de-açúcar em dietas com elevada proporção de concentrados para novilhos Nelore em confinamento. (In portuguese.) R. Bras. Zootec. 32:1786-1791. doi:10.1590/ S1516-35982003000700029.

Licitra, G., T. M. Hernandez, and P. J. Van Soest. 1996. Standardization of procedures for nitrogen fractionation of ruminant feeds. Anim. Feed Sci. Technol. 57:347-358. doi:10.1016/0377-8401(95)00837-3.

Lofgreen, G. P., and W. N. Garrett. 1968. A system for expressing net energy requirements and feed values for growing and finishing beef cattle. J. Anim. Sci. 27:793-806.

MacDonald, J. C., K. H. Jenkins, F. T. McCollum, and N. A. Cole. 2011. Effects of level of alfalfa hay in steam-flaked corn based diets containing 25\% sorghum wet distiller's grains. http://amarillo.tamu.edu/files/2011/01/Effects-of-Level-ofAlfalfa-Hay.pdf. (Accessed 26 April 2015.)

Marcondes, M. I., S. C. Valadares Filho, I. M. Oliveira, P. V. R. Paulino, R. F. D. Valadares, and E. Detmann. 2011. Eficiência alimentar de bovinos puros e mestiços recebendo alto ou baixo nível de concentrado. (In portuguese.) R. Bras. Zootec. 40:1313-1324. doi:10.1590/S1516-35982011000600021.

May, M. L., M. J. Quinn, N. DiLorenzo, D. R. Smith, and M. L. Galyean. 2011. Effects of roughage concentration in steamflaked corn-based diets containing wet distiller's grains with solubles on feedlot cattle performance, carcass characteristics, and in vitro fermentation. J. Anim. Sci. 89:549-559. doi:10.2527/jas.2010-3049. 
Millen, D. D., R. D. L. Pacheco, M. D. B. Arrigoni, M. L. Galyean, and J. T. Vasconcelos. 2009. A snapshot of management practices and nutritional recommendations used by feedlot nutritionists in Brazil. J. Anim. Sci. 87:3427-3439. doi:10.2527/jas.2009-1880.

Mooney, C. S., and M. S. Allen. 1997. Physical effectiveness of the neutral detergent fiber of whole linted cottonseed relative to that of alfalfa silage at two lengths of cut. J. Dairy Sci. 80:2052-2061.

Moore, R. L., H. W. Essig, and L. J. Smithson. 1975. Influence of breeds of beef cattle on ration utilization. J. Anim. Sci. 41:203-207.

NRC. 1984. Nutrient requirements of beef cattle. 6th ed. Natl. Acad. Press, Washington, DC.

NRC. 1996. Nutrient requirements of beef cattle. 7th ed. Natl. Acad. Press, Washington, DC.

Nuñez, A. J. C., M. Caetano, A. Berndt, J. J. A. A. Demarchi, P. R. Leme, and D. P. D. Lanna. 2013. Combined use of ionophore and virginiamycin for finishing Nellore steers fed high concentrate diets. Sci. Agric. (Piracicaba, Braz.) 70:229-236. doi:10.1590/S0103-90162013000400002.

Olbrich, J. F., Jr. 1996. The effect of corn particle size and corn silage level on the performance of Angus (Bos taurus) and Brahman (Bos indicus) steers. PhD Diss., Univ. Florida, Gainesville, FL.

Owens, F. N., and R. A. Zinn. 2005. Corn grain for cattle: Influence of processing on site and extent of digestion. In: Proc. Southwest Nutr. Conf., Tucson, Arizona. p. 86-112.

Owens, F. N., R. A. Zinn, and Y. K. Kim. 1986. Limits to starch digestion in the ruminant small intestine. J. Anim. Sci. 63:1634-1648.

Parsons, C. H., J. T. Vasconcelos, R. S. Swingle, P. J. Defoor, G. A. Nunnery, G. B. Salyer, and M. L. Galyean. 2007. Effects of wet corn gluten feed and roughage levels on performance, carcass characteristics, and feeding behavior of feedlot cattle. J. Anim. Sci. 85:3079-3089. doi:10.2527/jas.2007-0149.

Philippeau, C., F. Le Deschault De Monredon, and B. Michalet-Doreau. 1999. Relationship between ruminal starch degradation and the physical characteristics of corn grain. J. Anim. Sci. 77:238-243.

Pritchard, R. H. 1998. Bunk management: observations from research. http://amarillo.tamu.edu/files/2010/10/1998PNCProceedings.pdf. (Accessed 25 April 2015.)
Shain, D. H., R. A. Stock, T. J. Klopfenstein, and D. W. Herold. 1999. The effect of forage source and particle size on finishing yearling steer performance and ruminal metabolism. J. Anim. Sci. 77:1082-1092.

Silva, S. L., P. R. Leme, S. M. Putrino, A. C. Valinote, J. C. M. Nogueira Filho, and D. P. D. Lanna. 2007. Milho grão seco ou úmido com sais de cálcio de ácidos graxos para novilhos Nelore em confinamento. (In portuguese.) R. Bras. Zootec. 36:1426-1434. doi:10.1590/S1516-35982007000600028.

Stock, R. A., M. H. Sindt, J. C. Parrott, and F. K. Goedeken. 1990. Effects of grain type, roughage level and monensin level on finishing cattle performance. J. Anim. Sci. 68:3441-3455.

Van Soest, P. J., J. B. Robertson, and B. A. Lewis. 1991. Methods for dietary fiber, neutral detergent fiber, and nonstarch polysaccharides in relation to animal nutrition. J. Dairy Sci. 74:3583-3597. doi:10.3168/jds.S0022-0302(91)78551-2.

Weiss, W. P., H. R. Conrad, and N. R. St Pierre. 1992. A theoretically-based model for predicting total digestible nutrient values of forages and concentrates. Anim. Feed Sci. Technol. 39:95-110. doi:10.1016/0377-8401(92)90034-4.

Wise, M. B., R. W. Harvey, B. R. Hankins, and E. R. Barrick. 1968. Finishing beef cattle on all-concentrate rations. J. Anim. Sci. 27:1449-1461.

Yu, P., J. T. Huber, F. A. P. Santos, J. M. Simas, and C. B. Theurer. 1998. Effects of ground, steam-flaked, and steam-rolled corn grains on performance of lactating cows. J. Dairy Sci. 81:777-783. doi:10.3168/jds.S0022-0302(98)75634-6.

Zinn, R. A., L. Corona, and R. A. Ware. 2004. Forage quality: Impacts on cattle performance and economics. http://alfalfa. ucdavis.edu/+symposium/proceedings/2004/04-209.pdf. (Accessed 26 April 2015.)

Zinn, R. A., F. N. Owens, and R. A. Ware. 2002. Flaking corn: Processing mechanics, quality standards, and impacts on energy availability and performance of feedlot cattle. J. Anim. Sci. 80:1145-1156.

Zinn, R. A., and Y. Shen. 1998. An evaluation of ruminally degradable intake protein and metabolizable amino acid requirements of feedlot calves. J. Anim. Sci. 76:1280-1289. 
Reproduced with permission of the copyright owner. Further reproduction prohibited without permission. 